\title{
COMPARISON OF DISTAL THIRD FOREARM FRACTURES IN CHILDREN TREATED WITH ABOVE ELBOW VERSES BELOW ELBOW CAST.
}

\author{
1. MBBS, M.S. (Ortho) \\ Associate Professor \\ Department of Orthopedics \\ Faisalabad Medical University, \\ Faisalabad. \\ 2. MBBS \\ Medical Officer \\ Department of Orthopedics \\ Allied Hospital, Faisalabad. \\ 3. MBBS, FCPS (Ortho) \\ Senior Registrar \\ Department of orthopedics, \\ Allied Hospital, Faisalabad. \\ 4. MBBS, FCPS (Ortho) \\ Professor \\ Department of Orthopedics \\ Faisalabad Medical University, \\ Faisalabad. \\ 5. FCPS \\ Senior Registrar \\ Department of Orthopedics \\ PMC/ Allied Hospital Faisalabad. \\ Correspondence Address: \\ Dr. Basharat Manzoor \\ Department of orthopedics, \\ Faisalabad Medical University, \\ Faisalabad. \\ drbasharat5050@gmail.com \\ Article received on: \\ 13/04/2019 \\ Accepted for publication: \\ $25 / 08 / 2019$
}

\section{INTRODUCTION}

About $75 \%$ of forearm fractures in children are distal one third of forearm fracture ${ }^{1}$ some fracture may included radius, Ulna or both radius \& ulna involving metaphyseal, physeal or intracarticular. ${ }^{2}$ Closed reduction and plaster casting, closed reduction and percutaneous k-wiring are the version modalities for the treatment of distal one third forearm fracture in children. Closed reduction and immobilization of the these fracture are the most common means of management of these fracture in children. ${ }^{3}$

In the management of the fracture above elbow cast has been used to immobilize the elbow joint to prevent re displacement of the fragments of the fracture.

Some orthopedic surgeon used the short arm

\begin{abstract}
Basharat Manzoor ${ }^{1}$, Waseem Yousaf ${ }^{2}$, M Irfan Fareed ${ }^{3}$, M. Javed Iqbal Awan ${ }^{4}$, Sajjad Iqbal ${ }^{5}$ Objectives: To compare the result of above elbow cast with below elbow cast in the treatment Aus $(n=41)$ were between $1-6$ years of age while. In group A $61.11 \%(n=55)$ and group B $54.44 \%$ $(n=49)$ were 7-12 years of age of the children mean \pm sd $7.66 \pm 2.54$ and $7.38 \pm 2.46$ years espectively, In group A $58.89 \%(n=53)$ in group B 62.22\% $(n=56)$ were male while group -A (N37) and in group B 37.78\% were females below elbow cast compared with above $(n+21)$ and group B 30\% ( $n=27)$ and re displacement shows no significant difference between their two groups. Conclusion: We concluded there is no significant difference in outcome of above elbow cast with below elbow cast after reduction treating the fracture of children in distal on third forearm fractures.
\end{abstract}

Key words: $\quad$ Above Elbow Cast, Below Elbow Cast, Children, Comparison, Distal One Third Forearm.

Article Citation: Manzoor B, Yousaf W, Fareed MI, Awan MJI , Iqbal S. Comparison of distal third forearm fractures in children treated with above elbow verses below elbow cast. Professional Med J 2019; 26(11):1989-1992.

DOI: 10.29309/TPMJ/2019.26.11.3816

cast with equally results. Reducing the supination and pronation movements at the wrist joint with well molded short cast can reduce the chances of redislplacement. ${ }^{4,5}$

Common complication after reduction of these fractures is re displacement. Displacement after closed reduction and application of cast is to increase due residual angulation of radial fracture \& ulnar plastic deformity. Re-manipulation needed after re displacement in many cases. ${ }^{6,7}$

In children fracture of the distal one third of the forearm are immobilizated after closed reduction with above elbow plaster cast, although some orthopedic surgeon use the below elbow plaster cast to immobilize the forearm. In determining the outcome, there exists a contradiction. Children under went manipulation and casting above 
elbow cast 71 , and 8 below elbow casts. Below elbow plaster $38 \%$ and in above elbow cast $4.21 \%$ needs remanipulaction after re displacement in cast radiologically assessment. (Fraser moodce JA et. $\mathrm{Al}^{7}$ )

$19.6 \%$ of children in above elbow cast group needs re manipulation after redisplacement compared with $26.4 \%$ in the below elbow cast group P-value (=0.381) Rehman et al,.8

\section{MATERIALS AND METHODS OBJECTIVE}

The outcome of below elbow cast \& above elbow cast immobilization after reduction in treatment of distal one third forearm fractures in children.

\section{Study Design}

Randomized

\section{Duration of Study}

One years 14-Sep, 2015 to 15-Aug, 2016.

\section{Setting}

Department of Orthopedics Allied Hospital, Faisalabad.

\section{Inclusion Criteria}

Both female \& male

1-12 years of age

ON X-ray fracture of distal one third radius / Ulna

\section{Exclusive Criteria}

ON X-Rays

- Plastic Deformities

- Green Stick fracture

- Intra articular fractures

- Epiphyseal injuries

- And pathological fractures

A total of 180 cases were included in our study compare the result of above elbow cast with below elbow cast in the management of distal one third forearm fracture in children those totally the inclusion \& exclusion criteria regarding to age distribution.

\section{RESULTS}

In group A 38.89\% $(n=35)$ in group B $45.56 \%$ $(\mathrm{n}=41)$ were between 1-6 years while in group $A$ $61.11 \%(n=55)$ and in group B $54.44 \%(n=49)$ were between 7-12 year of age group, mean $+\mathrm{sd}$ $7.66 \pm$ year of age group, mean + sd $7.66 \pm$ 2.54 and $7.38 \pm 2.46$ years respectively (Table-I) regarding to gender distribution of the patients group A 58.89\% $(n=53)$ and group-A $41.11 \%$ $(n=37)$ and in group B $37.78 \%(n=34)$ were females (Table-II).

Outcome of results of above elbow \& below elbow plaster cast in the treatment of distal one third forearm fracture in children shows in group -A 23.33\% $(n=21)$ and in group B 30\% $(n=27)$ had group B 70\% $(n=63)$ had no re displacement, regarding $P$ value $(0.312)$ there is no significant difference in two groups (Table-III).

Re displacement stratification was done in these groups. 9 Cases in group A \& 12 causes in group $B$ between age 1-6 years, $P$ Value was 0.72 while in group A 12 cases \& 15 cases of group-B for re displacement were between age group 7-12 years and P-value was 0.30 (Table-IV).

Re displacement stratification was done in the two group regarding to gender. In group A 11 patients and in group $B 15$ patients for re displacement were male, $P$ value was 0.45 . On the other hand in group A 16 patients \& in group B 12 patients for re displacement were females, + value was 0.49. (Table-V)

\begin{tabular}{|c|c|c|c|c|}
\hline \multirow{2}{*}{$\begin{array}{c}\text { Age } \\
\text { (in } \\
\text { Years) }\end{array}$} & \multicolumn{2}{|c|}{$\begin{array}{c}\text { Group-A } \\
(n=90)\end{array}$} & \multicolumn{2}{|c|}{$\begin{array}{c}\text { Group-B } \\
(n=90)\end{array}$} \\
\hline & $\begin{array}{c}\text { No. of } \\
\text { Patients }\end{array}$ & $\%$ & $\begin{array}{c}\text { No. of } \\
\text { Patients }\end{array}$ & $\%$ \\
\hline $1-6$ & 35 & 38.89 & 41 & 45.56 \\
\hline $7-12$ & 55 & 61.11 & 49 & 54.44 \\
\hline Total & 90 & 100 & 90 & 100 \\
\hline Mean \pm sd & \multicolumn{2}{|c|}{$7.66+2.54$} & \multicolumn{2}{|c|}{$7.38+2.46$} \\
\hline \multicolumn{5}{|c|}{ Table-I. Age distribution $(n=180)$} \\
\hline \multirow{2}{*}{ Gender } & \multicolumn{2}{|c|}{$\begin{array}{l}\text { Group-A } \\
(n=90)\end{array}$} & \multicolumn{2}{|c|}{$\begin{array}{l}\text { Group-B } \\
(n=90)\end{array}$} \\
\hline & $\begin{array}{c}\text { No. of } \\
\text { Patients }\end{array}$ & $\%$ & $\begin{array}{c}\text { No. of } \\
\text { Patients }\end{array}$ & $\%$ \\
\hline Male & 53 & 58.89 & 56 & 62.22 \\
\hline Female & 37 & 41.11 & 34 & 37.78 \\
\hline Total & 90 & 100 & 90 & 100 \\
\hline \multicolumn{5}{|c|}{ Table-II. Gender distribution $(n=180)$} \\
\hline
\end{tabular}




\begin{tabular}{|c|c|c|c|c|}
\hline \multirow{2}{*}{ Outcome } & \multicolumn{2}{|c|}{$\begin{array}{c}\text { Group-A } \\
(\mathbf{n = 9 0 )}\end{array}$} & \multicolumn{2}{c|}{$\begin{array}{c}\text { Group-B } \\
(\mathbf{n = 9 0 )}\end{array}$} \\
\cline { 2 - 5 } & $\begin{array}{c}\text { No. of } \\
\text { Patients }\end{array}$ & $\%$ & $\begin{array}{c}\text { No. of } \\
\text { Patients }\end{array}$ & $\%$ \\
\hline Yes & 21 & 23.33 & 27 & 30 \\
\hline No & 69 & 76.67 & 63 & 70 \\
\hline Total & 90 & 100 & 90 & 100 \\
\hline
\end{tabular}

Table-III. Comparison of outcome of below the elbow cast with above the elbow cast in treating distal third forearm fracture in children $(n=180)$

$P$ value $=0.312$

Age: 1-6 Years

\begin{tabular}{|l|c|c|c|}
\hline \multirow{2}{*}{ Group } & \multicolumn{2}{|c|}{ Re-displacement } & P-Value \\
\cline { 2 - 3 } & Yes & No & \\
\hline A & 9 & 26 & 0.72 \\
\hline B & 12 & 29 & \\
\hline
\end{tabular}

Age: 7-12 Years

\begin{tabular}{|l|c|c|c|}
\hline \multirow{2}{*}{ Group } & \multicolumn{2}{|c|}{ Re-displacement } & P-Value \\
\hline A & Yes & No & \\
\hline B & 12 & 43 & 0.30 \\
\hline
\end{tabular}

Table-IV. Stratification for outcome in the two groups with regards to age $(n=180)$

Male

\begin{tabular}{|l|c|r|r|}
\hline \multirow{2}{*}{ Group } & \multicolumn{2}{|c|}{ Re-displacement } & P-Value \\
\cline { 2 - 3 } & Yes & No & \\
\hline A & 11 & 42 & 0.45 \\
\hline B & 15 & 41 & \\
\hline
\end{tabular}

Female

\begin{tabular}{|l|c|c|c|}
\hline \multirow{2}{*}{ Group } & \multicolumn{2}{c|}{ Re-displacement } & P-Value \\
\cline { 2 - 3 } A & Yes & No & \multirow{2}{*}{0.49} \\
\hline B & 16 & 21 & 22 \\
\hline \\
Table-V. Stratification for outcome in the two groups \\
with regards to gender $(\mathbf{n = 1 5 0 )}$
\end{tabular}

\section{DISCUSSION}

The most common fractures of childhood are the closed fractures of the distal one third of the forearm closed reduction of the fracture and immobilization with above elbow cast is the method of management, although by some orthopedic surgeons used to immobilize the fracture after the reduction of the fracture with elbow cast.
In our study in we planned to compare the results of above elbow plaster cast with below elbow plaster cast in managing the distal one third forearm fracture in children.

In our study in group A $38.89 \%$ (n35), in group $45.46 \%(n=41)$ were 1-6 year, while in group $A$ $61.11 \%(n=55)$ and group B 54.44\% $(n=49)$ were $7-12$ years of age, mean $\pm \mathrm{sd}$ was $7.66 \pm 2.54$ and $7.38 \pm 2.46$ years respectively. In group A 58.89 $\%(n=53)$ in group B 62.22\% $(n=56)$ were male, while in group A $41.11 \%(n=37)$ and in group $B$ $37.78 \%(n=34)$ were females child patients.

Results of above elbow plaster cast with below elbow plaster cast regarding the management of distal one third forearm fracture in children shows that in group A 23.33\% $(n=21)$ and group B 30\% $(n=27)$ had re displacement, shows no significant difference in these groups.

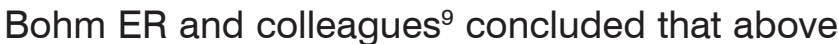
elbow cast and below elbow cast are similar in maintaining reduction of fracture and complication rates in distal one third of the forearm fracture in children.

Paneru SR ${ }^{10}$ and others concluded that above elbow cast as well as below elbow cast management of the fracture in distal one third forearms in children complications rate and total cast was higher which could be reduced by below elbow cast treatment.

\section{CONCLUSION}

In our sturdy we concluded that there is no significant difference in results treating the distal foramen fracture after reduction with above elbow cast and below elbow cast in children.

\section{Copyright(C 25 Aug, 2019.}

\section{REFERENCES}

1. Abraham A, Handoll HHG, Khan T. Summary of 'Interventions for treating wrist fractures in children' including tables of key findings and quality of included trials. Evid.-Based Child Health 2009; 378-81.

2. Meena S, Trikha V, Sambharia AK. Elbow dislocation with ipsilateral distal radius fracture. J Nat Sci Biol Med 2013; 4:479-81. 
3. Edmonds EW, Capelo RM, Newton PO. Predicting initial treatment failure of fiberglass casts in pediatric distal angle. J Child Orthop 2009; 3:375-81.

4. Hendrickx RP, Campo MM, van Lieshout AP, Struijs PA, van den Bekerom MP. Above- or below-elbow casts for distal third forearm fracture in children? A metaanalysis of the literature. Arch orthop Trauma Surg. 2011; 131(12)1663-71.

5. Leersput WV, Ridder KD. Distal metaphyseal radius fracture in children: Reduction with or without planning. Acta Orthop Belg 2009; 75: 306-9.

6. Shrestha D, Dhoju D, Parajuli N, Dhakal G, Shrestha R. Management of pediatric displaced distal metaphyseal forearm fracture: Comparison between cast immobilization and percutaneous kirschner wire fixation. Nep Orthop Assoc J 2011; 2: 1-6.
7. Fraser-Moodie JA, Bell S, Huntley JS. Above versus below elbow casts following manipulation of pediatric forearm fracture: Is the existing literature consistent with our experience? Bone Joint J 2013; 95:31-4.

8. Rodriguez-Merchan EC. Pediatric fractures of the forearm. Clin Orthop Relat Res 2005; 65.

9. Bohm ER1, Bubbar V, Yong Hing K, Dzus A. Above and below-the-elbow plaster casts for distal forearm fractures in children. A randomized controlled trial. J Bone Joint Surg Am. 2006 Jan; 88(1):1-8.

10. Paneru RS, Rijal R, Rai P. Randomized controlled trial comparing above - and below-elbow plaster casts for distal forearm fractures in children. $J$ Child Orthop 2010; 4:233-7.

\begin{tabular}{|c|c|c|c|}
\hline \multicolumn{4}{|c|}{ AUTHORSHIP AND CONTRIBUTION DECLARATION } \\
\hline Sr. \# & Author(s) Full Name & Contribution to the paper & Author(s) Signature \\
\hline 1 & Basharat Manzoor & Author & 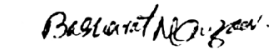 \\
\hline 2 & Waseem Yousaf & Data Collection & \\
\hline 3 & M Irfan Fareed & Data analysis & \\
\hline 4 & M. Javed lqbal Awan & Proof Reading & \\
\hline 5 & Sajjad lqbal & Final Reivew & \\
\hline
\end{tabular}

